board, but the perception of the persecutor.

Justice La Forest notes that this principle would also apply to each of the other four grounds. (Par. 120)

The court concludes that Mr. Ward feared persecution from the INLA because his political opinion opposes their stance on hostage taking.

Throughout this far-reaching examination of the law governing refugee status, the court keeps in centre-view the goal of protecting the human rights of those who have no effective protection in their home state. In order to best achieve this end, itincludes in the definition those whom the state cannot protect from nonstate persecutors and those who are persecuted on grounds analogous to the original four grounds identified by the Convention definition. Nonetheless, it recognizes that Canada's international obligations only extend to those who have no other options for protection in their own countries. It concludes that Mr. Ward was persecuted by the INLA because of his political opinion and that he could not be protected by the Irish authorities, but it directs the case back to the refugee board to decide if he would be able to find protection in Britain, his second country of citizenship. Thus, Convention refugee status is reserved for those who have noalternative but to seek international protection after a failure of domestic protection of their human rights.

The decision in Attorney General of Canada v. Ward brings Canadian law one large step closer to ensuring that those in danger of human rights violations receive protection. Professor James Hathaway has observed that this decision is "easily the most far-ranging decision issued by the senior court of any country."

\section{Note}

1. James Hathaway, Canada 0 . Ward: Table of Concordance to the Law of Refugee Status, July 1993, unpublished. Note that paragraph numbers correspond to those of the preliminary version of Canada $v$. Ward [1993] SC] 74, June 30, 1993.

\title{
The New Public Security Portfolio
}

\author{
Honourable Douglas Lewis, P.C., M.P.
}

Let me say, at the very outset of my remarks, that the organizational changes introduced last month do not alter in any wayCanada'simmigration policy. There has been no shift in the focus of that policy. We begin and end any debate with the certainty that immigration is good for Canada.

It has often been said before that sometimes it sounds like a religious chant, but the plain fact is we are a nation built by immigrants; to reach Canada's full potential we must increaseour population. There are many reasons. Let me give you one. It is easier to supply residents of California with consumer products than Canada's 27 million, 75 percent of whom are within 175 kilometres of the 6,000-kilometre Canadian-U.S. border.

As the grandson of an immigrant, I believe Canada's position in the world community owes as much to the genus and energy of waves of new Canadians as it does to our wealth in natural resources. And if you listen closely to those who predict the future, you will hear them say that it is our human resources that are the key to Canada's future prosperity.

That is why immigration has been an integral element of this government's social and economic agenda since 1984. We believe that the economic and social contributions made by new Canadians are essential to Canadian growth.

A decade ago, at a height of a previous recession, the government slashed immigration. This government chose another path. During nine years in office,

This article was extracted from notes for an address by the Honourable Douglas Lewis, Minister of Public Security, at a meeting with the representatives of ethnocultural agencies in Toronto on July 19, 1993. It is reproduced here in the hope of gleaning some insight on what to expect in the new public security approach to refugee matters in Canada-an approach that has not yet been satisfactorily outlined. we have gradually increased the annual level of immigration. In 1993, Canada will welcome as many as $250,000 \mathrm{immi}-$ grants-almost three times the number we welcomed in 1983.

Our record demonstrates our belief in the importance of immigration. We have no intention of changing.

The approach we have taken towards immigration matters can probably best be described as yanking Canada's head out of the sand. The world is changing and we had better be prepared to meet the challenges it poses or lose control of valuable programs like immigration.

The global community is awash with people seeking new homes. This is a phenomenon that has steadily grown over the past decade. A United Nations report estimates that more than 100 million people are on the move as migrants or refugees.

In these circumstances, faced with this rising tide of humanity, developed nations such as Canada have two basic options. They can either retreat behind high walls or work to manage those pressures at home and seek solutions to the root causes of migration in the source countries. We can either reinforce and defend the integrity of a generous and valuable immigration policy, or we can watch public confidence and support for the policy collapse.

We choose to take action and not to retreat. During the past eight years, we have either reinforced existing programs or established new programs to help newcomers adjust to life in Canada. We rebuilt Canada's refugee determination system and introduced a specific fiveyear plan for immigration levels. Last winter, we passed Bill C-86. The legislation updated Canada's Immigration Act for the first time since 1976.

But through all these reforms, the heart of Canada's immigration policy has remained unchanged. Its primary objective is still to bring to Canada individuals who can contribute to our eco- 
nomic development and to reunite families and protect refugees. At the same time, the series of new measures introduced with Bill C-86 allow Canada to address the realities of the $1990 \mathrm{~s}$. These measures will assist us to more effectively select newcomers and to accelerate their processing. They allow us to better protect a vital national program and $\mathrm{Ca}$ nadians from those who would abuse our generosity or break our immigration laws, and they further streamline a highly regarded refugee determination system.

The changes we proposed in C-86 were hotly debated. They didn't satisfy those people who wanted us to slam the door on immigration, and they weren't supported by those who told us to throw the door wide-open. Instead, they appealed to the vast majority of Canadians who found themselves between two viewpoints.

I believe that an effective immigration policy for Canada must balance our compassionate character as a people with our pragmatic requirements as a nation. The policy changes we introduced with C-86 achieved that goal. I am confident that the broad middle ground of public opinion views those changes in the same way-as balanced, fair and pragmatic. It is this same sense of pragmatism which motivated the prime minister to place large elements of this vital national policy within the protective envelope of the Public Security portfolio.

Again, we have chosen action over inaction. Since we took office in 1984, we have pursued a policy of growth in immigration levels because we are convinced of the benefits of this policy. Last Winter, Bill C- 86 gave us the tools to effectively meet the challenges and opportunities of immigration in the $1990 \mathrm{~s}$. Now, the reorganization of departmental responsibilities will permit us to better integrate a range of government functions that have complemented each other in the past.

For example, customs officers and the RCMP have had a long and close association with the immigration program. Each organization operates within its own area of jurisdiction, but each has certain responsibilities in helping to manage the arrival of immigrants, refugees or visitors to Canada. The establishment of the new department draws the threads of these various organizations more closely together.

Canada and Canadians will benefit from these changes through improvements in the management of our immigration policy and programs and through more effective control over the security of our borders.

Claims to the contrary, there is nothing in this reorganization of responsibilities that signals a shift in Canada's immigration policy. The government remains absolutely committed to the immigration policy as set out in the Immigration Act.

I will not deny that we have given extra weight to the issue of enforcement by placing key elements of the immigration program within a Public Security portfolio. This action is intended to preserve the integrity of a bedrock policy for Canada.

I know we both share the same anger when a foreign criminal slips through the system to claim the rights of Canadian citizenship. I know we share the same revulsion when an unscrupulous consultant is caught swindling defenceless migrants. And I know that we share the same knowledge that these incidents are the exception and not the rule. They do not represent the true face of immigration.

It is also true that senseless and violent attacks on new Canadians is a malicious assault on the basic sensibilities of all Canadians. This is not the Canada that generations of immigrations have worked to build. This must not be our future. As Minister of Public Security, I am determined to deal forcefully with the corrosive hatred of racial intolerance which pits Canadian against Canadian. There can be no tolerance for intolerance in Canada.

I believe we must do more to celebrate the success of immigration as part of the counterbalance to the hatred by ignorance. Immigration success stories far outweigh the controversies. Of the 220,000 newcomers who arrived in 1991, only a very tiny percentage were mired in controversy.
Unfortunately, that is not a perspective which many Canadians share. The sad fact is controversy attracts attention.

A recent report prepared by researchers for the Fraser Institute of Vancouver found that Canada's main television networks in general cast news stories on immigrants and refugees in a negative light.

Let me quote one of the researchers. She said, "The lack of attention to the positive economic impact of immigration has allowed the public to continue to believe that immigrants...are generally a liability rather than an asset for Canada." But while abuses are generally small in number, this does not preclude the need for enforcement measures. An immigration policy is worthless without the ability to enforce removal or deny entry to a country's sovereign territory. The United Nations High Commissioner for Refugees readily acknowledges this fact.

By consolidating management of our border activities and our immigration enforcement activities, I am convinced that we can exercise more effective control over entry to Canada, ensure that we better protect all Canadians, and reduce abuse of Canada's generous immigration and refugee programs.

When the prime minister announced the changes to the government's structure, she was asked if it was wise to call a new department, the department of Public Security.

She simply replied that one suggestion had been to call the department, the department of Home Affairs. "That's a lovely and elegant term," she said, "except if you ask Canadians what's in the department of Home Affairs, they wouldn't have the foggiest clue." "Let's start a new government," said the prime minister, "by communicating with Canadians in a language they understand."

There is no hidden agenda in the creation of this new department. There is just a profound commitment to the importance of the tasks at hand-that is the protection of Canadian society from those who would break our laws and preservation of a vital national policy which has contributed to our sense of identity and served as a source of prosperity for more than a century. 1. 